\title{
Suppression of annual bromes impacts rangeland: Vegetation responses
}

\author{
MARSHALL R. HAFERKAMP, R.K. HEITSCHMIDT, ELAINE E. GRINGS, MICHAEL D. MACNEIL, \\ AND MICHAEL G. KARL
}

Authors are rangeland scientist, supervisory rangeland scientist, research animal scientist, research geneticist, and postdoctoral rangeland scientist USDAARS, Fort Keogh Livestock and Range Res. Lab., Miles City, Mont. 59301. Karl is currently rangeland management specialist, USDI-Bureau of Land Management, Washington, DC 20240.

\begin{abstract}
Presence of invading annual bromes (Bromus spp.) can alter seasonal patterns of forage production and quality and require management changes for efficient use of infested rangelands in the Northern Great Plains. We studied biological impacts of the presence of brome by comparing brome infested rangeland to similar sites in which brome had been suppressed with autumn applications of atrazine [6-chloro-N-ethyl-N'-(1-methylethyl)1,3,5-triazine-2,4-diamine] at $0.56 \mathrm{~kg} \mathrm{ha}^{-1}$ in 1992 and 1993. Each treatment was randomly assigned to three, 12-ha pastures. Vegetation was measured for 5 months (May to September) each year from 1993 to 1995. Each pasture was stocked with 8 crossbred steers (Bos taurus) from mid-May to mid-September 1993 and 1995 and to mid-August 1994. The forage base varied temporally by date and year, but generally was not less than $800 \mathrm{~kg} \mathrm{ha}^{-1}$. Brome suppression increased $(P \leq \mathbf{0 . 0 5})$ crude protein concentration for western wheatgrass (Pascopyrum smithii Rydb. [Love]) in July (7.1 vs. 9.1\%) and August (6.0 vs. $7.1 \%)$. With the variation in annual brome stands among years, as influenced by growing conditions, this experiment demonstrated that improvement in forage nutritional quality can be expected from suppression of annual bromes on semiarid rangelands.
\end{abstract}

Key Words: Bromus japonicus, Pascopyrum smithii, Northern Great Plains, standing crop, forage quality

Japanese (Bromus japonicus Thunb.) and downy brome (Bromus tectorum L.) have invaded thousands of hectares of Northern Great Plains rangeland over the past 30 years (Haferkamp et al. 1993, Whisenant 1990, Hewlett et al. 1981). Although annual bromes can produce large quantities of nutritious spring forage, they can have a negative impact on associated perennial forage species, such as western wheatgrass (Pascopyrum smithii Rydb. [Love]; Haferkamp et al. 1997, 1998,

The authors express appreciation to Bryon Bennett, Caralee Leidholt, Cheryl Murphy, Duane Bundy, and several summer aides for field assistance, and Mary Ellen French for assistance with graphics.

This paper is a contribution from the USDA-ARS and Montana Agr. Exp. Sta., Miles City, Mont.

USDA-ARS Northern Plains Area, is an equal opportunity/affirmative action employer, and all agency services are available without discrimination.

Manuscript accepted. 20 Jan. 2001.

\section{Resumen}

La presencia de "Bromos" anuales invasores (Bromus spp.) puede alterar los patrones estacionales de producción y calidad de forraje y requieren cambios de manejo para hacer un uso eficiente de los pastizales infestados de las Grandes Planicies del Norte. Estudiamos los impactos biológicos de la presencia del "Bromo"mediante la comparación de pastizales infestados con sitios similares en los cuales el "Bromo" había sido suprimido con aplicaciones en otoño de atrazina [6-cloro-N-etil-N'-(1-metiletil)1,3,5-triazina-2,4-diamina] en dosis de $0.56 \mathrm{~kg} \mathrm{ha}^{-1}$ efectuadas en 1992 y 1993. Cada tratamiento se asignó aleatoriamente a tres potreros de 12 ha. De 1993 a 1995 la vegetación se midió anualmente durante 5 meses (Mayo a Septiembre). En 1993 y 1995, de mediados de Mayo a mediados de Septiembre, cada potrero se cargó con 8 novillos de cruzas comerciales (Bos taurus) y en 1994 se utilizaron hasta mediados de Agosto. El forraje base varió temporalmente por fecha y año, pero generalmente no fue menor de $800 \mathrm{~kg} \mathrm{ha}^{-1}$. La supresión de "Bromo" incrementó $(\mathrm{P} \leq \mathbf{0 . 0 5})$ la concentración de proteína cruda del "Western wheatgrass" (Pascopyrum smithii Rydb. [Love]) en Julio (7.1 vs. 9.1\%) y Agosto (6.0 vs. $7.1 \%)$. Con la variación entre años de las poblaciones de "Bromo", por influencia de las condiciones durante el período de crecimiento, este experimento demostró que al suprimir el "Bromo" anual se puede esperar un mejoramiento en la calidad nutricional de los pastizales semiáridos.

Rummell 1946), and performance of grazers (Mosley 1996, Mayland et al. 1994, Fleming et al. 1942).

Annual forage production on brome infested rangelands fluctuates greatly with variations in amounts and distribution of precipitation (Haferkamp et al. 1993, Gartner et al. 1986) and soil N (McLendon and Redente 1994, Cline and Rickard 1993). Forage nutritional quality of annual bromes is comparable to that of perennial grasses at similar phenological stages. But, because annual bromes mature quickly (Vallentine and Stevens 1994), their presence can alter seasonal patterns of forage production and quality (Haferkamp et al. 1994) on infested rangelands.

We studied the biological impacts of the presence of brome by comparing brome infested rangeland to similar sites on which brome had been suppressed. Our hypothesis was that by suppressing annual brome forage production we would enhance perennial grass production and alter inter-seasonal forage quality dynamics. 


\section{Materials and Methods}

\section{Study Site}

Research was conducted at the Fort Keogh Livestock and Range Research Laboratory $\left(46^{\circ} 22^{\prime} \mathrm{N} 105^{\circ} 5^{\prime} \mathrm{W}\right)$ near Miles City, Mont. Elevation ranges from 716 to $853 \mathrm{~m}$. Regional topography ranges from rolling hills to broken badlands with small intersecting ephemeral streams flowing into rivers in broad, nearly level valleys. Indigenous vegetation on the 22,500-ha research station is a $\mathrm{grama-needle} \mathrm{gras} \mathrm{s-wheatgras} \mathrm{s}$ (Bouteloua-Stipa-Agropyron) mix (Kuchler 1964). Annual precipitation averages 343 mm, with about $60 \%$ received from April through September (Fig. 1). Daily temperatures range from $>38^{\circ} \mathrm{C}$ during summer to $<-40^{\circ} \mathrm{C}$ during winter. The average frost-free growing season is 150 days.

Soils at the specific study site are a composite of Absher heavy clays (Fine, smectitic, frigid Leptic Torrertic Natrustalfs) and Gerdrum silty clay loam (Fine, smectitic, frigid Torrertic Natrustalfs). Topography is gently sloping $(<2 \%)$. Vegetation is dominated by western wheatgrass, blue grama (Bouteloua gracilis [H.B.K.] Lag. ex Griffiths), Sandberg bluegrass (Poa secunda Presl.), sand dropseed (Sporobolus cryptandrus [Torr.] Gray), and Japanese brome. Threadleaf sedge (Carex filifolia Nutt.) is the dominant grasslike species. Dandelion (Taraxacum officinale Weber) and salsify (Tragopogon dubius Scop.) are the dominant forb species.

\section{Treatments and Experimental Design}

Six, 12-ha pastures treated with the Range Improvement Machine in 1982 (Haferkamp et al. 1993) were used in this study. Each of 2 brome treatments was randomly assigned to 3 pastures in autumn 1992. The treatments were (1) brome undisturbed and (2) brome suppressed with atrazine [6-chloro-N-ethyl-N'-(1methylethyl)-1,3,5-triazine-2,4-diamine] applied to dormant vegetation in November 1992 and 1993 at $0.56 \mathrm{~kg}$ a.i. $\mathrm{ha}^{-1}$. Herbicide was applied by ground in 1992 in 149.6 liters water $\mathrm{ha}^{-1}$ and by air in 1993 in 18.7 liters water ha' ${ }^{-1}$. No herbicide was applied in autumn 1994.

Each 12-ha pasture was stocked annually with 8 crossbred yearling steers (Bos taurus). Pastures were stocked continuously from mid-May until mid-September 1993 and 1995. Limited forage production in 1994 resulted in a shortened grazing season extending from mid-May to mid-
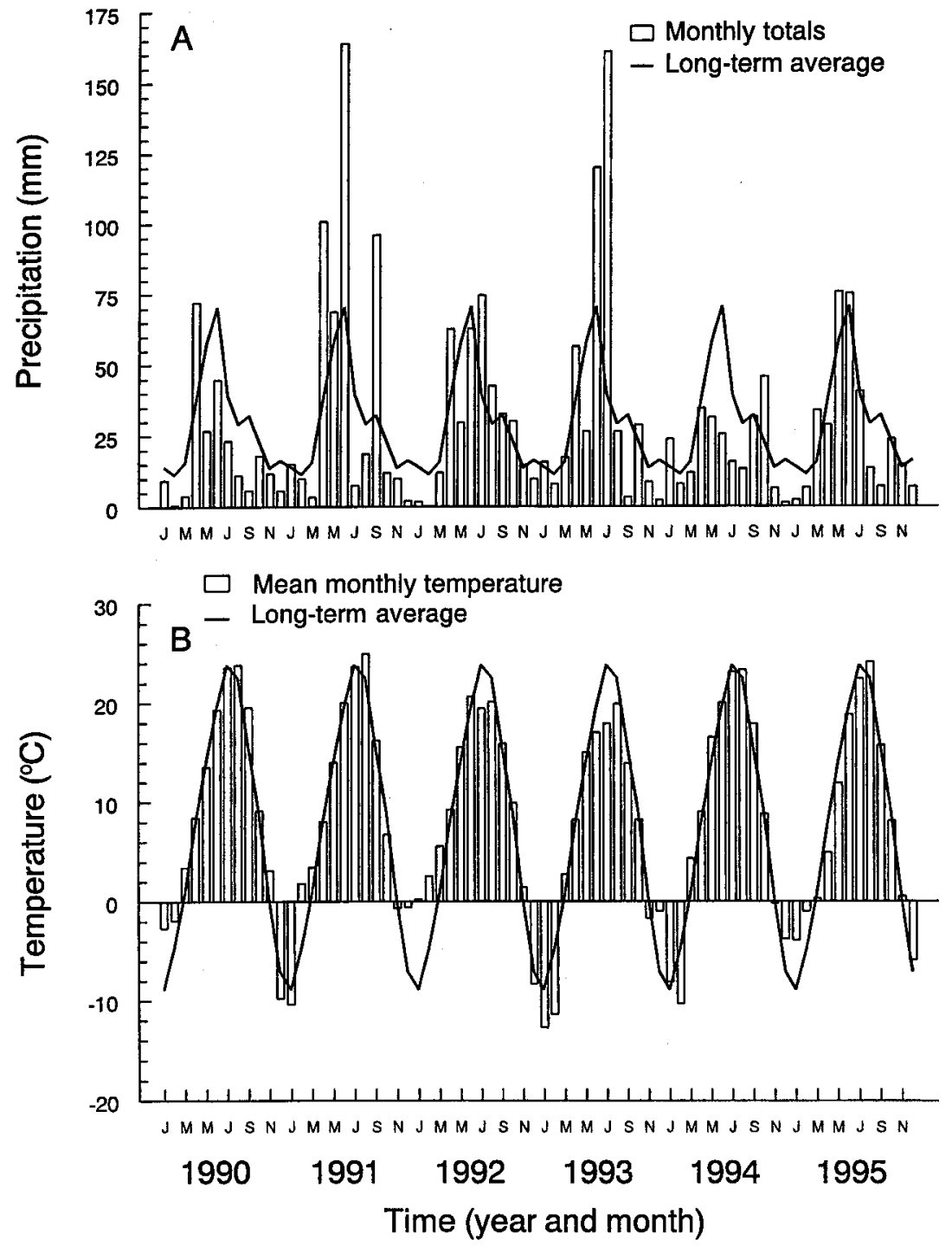

Fig. 1. (A) Precipitation and (B) temperature recorded at the Frank Wiley Airfield (National Oceanic and Atmospheric Administration 1990-1995) located about $11 \mathrm{~km}$ from the study sites for 1990 through 1995.

August. Initial weight of steers averaged $329 \mathrm{~kg}(\mathrm{SD}=31)$ in $1993,273 \mathrm{~kg}(\mathrm{SD}=$ $14)$ in 1994 , and $272 \mathrm{~kg}(\mathrm{SD}=21)$ in 1995. Steers were stratified by initial weight and within strata randomly assigned to pastures. Steers were handled according to protocol approved by the Fort Keogh Livestock and Range Research Laboratory Animal Care and Use Committee.

\section{Field Sampling \\ Pretreatment}

Current-year standing crop was estimated in June 1991 and May 1992 in all pastures just before the beginning of the grazing season by hand harvesting all herbage of the current year above a $25-\mathrm{mm}$ stubble height in fifteen, 30 by $60-\mathrm{cm}$ plots randomly located in each pasture. Herbage was separated by species or species groups, oven dried in a forced draft oven at $60^{\circ} \mathrm{C}$, and weighed. The species groups included Western wheatgrass + Sandberg bluegrass, other perennial grasses [mainly blue grama and buffalo grass (Buchloe dactyloides [Nutt.] Engelm.)], annual grasses [Japanese brome, downy brome, six-weeks fescue (Vulpia octoflora [Walter] Rydb.), and little barley (Hordeum pusillum Nutt.)], sedges, and forbs. These samples were collected during the interim between the current study and earlier experiments reported by Haferkamp et al. (1993). 


\section{Post-treatment}

One key area (50 m by $50 \mathrm{~m}$ ) was centrally located within each pasture prior to the initiation of grazing in 1993. Standing crop was sampled in all pastures by clipping and separating current-year herbage (live plus current-year dead) by plant species or species group. All herbage and previous year standing dead (old dead) as a composite of species were clipped to ground level in 10 randomly located circular $0.25-\mathrm{m}^{2}$ plots in each key area. Throughout the study samples were collected in May, June, July, August, and September, except September in 1994.

Ten, $1-\mathrm{m}$ by $1-\mathrm{m}$ cages were randomly located adjacent to key areas in early May each year. These were used to estimate above ground net primary production (ANPP) in August each year. Current-year (live plus current-year dead) and standing dead were clipped to ground level within a $0.25-\mathrm{m}^{2}$ plot located within each cage. Herbage samples were oven dried in a forced-draft oven at $60^{\circ} \mathrm{C}$ and weighed.

\section{Laboratory Analyses}

Samples were ground to pass through a 1-mm screen in a Wiley mill ${ }^{1}$ (Arthur $\mathrm{H}$. Thomas Co., Philadelphia, Penn.) for total $\mathrm{N}$ and in vitro digestible organic matter (IVDOM) determinations. Total N (organic matter basis) was determined with a Technicon Auto Analyzer (Technicon Industrial Systems 1977) ${ }^{1}$. Data are presented as crude protein (CP; percentage $\mathrm{N} * 6.25)$. In vitro digestible organic matter (IVDOM) was determined using a modified Tilley and Terry (1963) technique (White et al. 1981). Nitrate-N concentration was determined at a commercial laboratory by the ion electrode technique (AOAC 1990) on current year herbage of western wheatgrass collected in May and July each year.

\section{Data Summarization and Analysis Pretreatment}

Similarity of spring standing crop in pastures upon which brome suppression treatments were applied was tested with the residual variation among pastures within treatment for an analysis of variance model for randomly applied treatments with subsamples. Effects of brome suppression treatments on annual net primary production (ANPP) in August 1993,

\footnotetext{
${ }^{1}$ Mention of any trade name or proprietary product does not constitute a guarantee or warranty by the authors or USDA-ARS nor does it imply the approval of these products to the exclusion of others.
}

1994, and 1995, were tested with the residual variation among pastures within treatment. The Least Significant Difference (LSD) method ( $\mathrm{P} \leq 0.05)$ protected by a prior F-test $(\mathrm{P} \leq 0.05)$ was used for comparing treatment means (SAS 1990). All differences discussed are significant at the $\mathrm{P} \leq 0.05$ level unless otherwise noted.

\section{Post-treatment (grazed and ungrazed)}

Analysis of variance was used to test effects of treatments, years, dates, and interactions among them on standing crop. Treatment effects were tested using variation among pastures within treatment as error. Year and treatment by year interaction effects were tested using variability among pastures within year-treatment subclasses. Effects of date and interaction of date with other effects were tested with residual variation after accounting for all other effects in the model.

Comparisons were limited to May, June, July, and August, due to the lack of September samples in 1994. Most statistical analyses of biomass were run by species groups for total current-yearstanding crop (including current dead), total old standing dead, and total standing crop (including current and old standing dead). Percentage CP and IVDOM were statistically analyzed for selected species or groups making up a majority (68 to $94 \%$ ) of the species composition. Individual species included Japanese brome, western wheatgrass, blue grama, forbs, and standing dead. These analyses were run for other species, but as a result of lack of sample material many least square means were not estimable due to missing values.

\section{Results}

\section{Pre-treatment}

Late spring standing crop of all species groups, averaged for 1991 and 1992, were similar ( $\mathrm{P}=0.09$ to 0.91$)$ between pastures subsequently assigned brome suppression treatments (Table 1). Springtime estimates of annual grass biomass in current-year standing crop averaged $525 \mathrm{~kg}$ $\mathrm{ha}^{-1}$ in 1991 and 1992. This was considerably greater than the May standing crops of annual grasses in 1993, 1994, and 1995 (Table 2). The decline in annual grasses clearly shows this study was conducted with below maximum composition of annual grasses.
Table 1. Least-squares means $+\mathrm{SE}$ for ungrazed spring standing crop averaged for 1991 and 1992, the 2 years prior to application of brome suppression treatments. No significant differences were detected between treatments.

\begin{tabular}{lc}
\hline \hline Species group & Standing crop \\
\hline Western wheatgrass & $-\left(\mathrm{kg} \mathrm{ha}^{-1}\right)-$ \\
Sandberg bluegrass & $348 \pm 32$ \\
Forbs & $35 \pm 14$ \\
Other perennial grasses & $36 \pm 8$ \\
Annual grasses & $524 \pm 46$ \\
Sedges & $\mathrm{T} \pm 5$ \\
Total current year & $945 \pm 67$ \\
\hline
\end{tabular}

\section{Herbage Standing Crop}

Samples collected during the growing season reflected not only brome suppression but also the influences of precipitation, temperature, and grazing by cattle. The forage base varied temporally among dates and years (Table 2), but generally was not less than $800 \mathrm{~kg} \mathrm{ha}^{-1}$.

Annual grasses were reduced by brome suppression on each sample date in 1993 and 1995, but not in 1994 (Table 2). Total current-year standing crop and total standing crop were reduced by brome suppression in June and July 1993, August 1994, and July 1995.

Standing crop varied among dates within years (Table 2). The relatively large total standing crop in May 1994 resulted from the large amount of standing dead carried over from the relatively wet summer of 1993. Other perennial grasses were most prominent $(\mathrm{P}<0.01)$ in the July sample $\left(330 \mathrm{~kg} \mathrm{ha}^{-1}\right)$ and least prominent in May $\left(110 \mathrm{~kg} \mathrm{ha}^{-1}\right)$, whereas forbs decreased $(\mathrm{P} \leq$ 0.01 ) from a high in May and June of $85 \mathrm{~kg}$ $\mathrm{ha}^{-1}$ to $20 \mathrm{~kg} \mathrm{ha}^{-1}$ in August. Western wheatgrass + Sandberg bluegrass increased $(\mathrm{P} \leq$ 0.01 ) during 1993 and peaked in June and July 1995.

\section{Aboveground Net Primary Production From Cages}

Annual grass was the only component of ANPP affected by brome suppression. Brome suppression reduced $(\mathrm{P}<0.01)$ ANPP of annual grasses in 1993 (410 vs. $\left.25 \pm 42 \mathrm{~kg} \mathrm{ha}^{-1}\right)$, but not $1994(25 \pm 42 \mathrm{~kg}$ $\left.\mathrm{h}^{-1}\right)$ or $1995\left(168 \pm 42 \mathrm{~kg} \mathrm{ha}^{-1}\right)$. Above ground net primary production of western wheatgrass + Sandberg bluegrass $(1,405$ vs. $\left.820 \pm 140 \mathrm{~kg} \mathrm{ha}^{-1} ; \mathrm{P} \leq 0.05\right)$, forbs (180 vs. $\left.35 \pm 34 \mathrm{~kg} \mathrm{ha}^{-1} ; \mathrm{P} \leq 0.03\right)$, and total biomass $(2,213$ vs. $1,525 \pm 167 \mathrm{~kg}$ $\left.\mathrm{ha}^{-1} ; \mathrm{P} \leq 0.01\right)$ were also highest in 1993 . Amount of dead material was greatest $(\mathrm{P} \leq$ $0.03)$ in $1994\left(409 \pm 57 \mathrm{~kg} \mathrm{ha}^{-1}\right)$ and smallest in $1993\left(109 \pm 56 \mathrm{~kg} \mathrm{ha}^{-1}\right)$. 
Table 2. Least-squares means \pm SE for significant year by date by brome suppression treatment interaction for standing crop from grazed pastures. Comparisons are only made between brome suppression treatments and among dates within each year.

Year

Component

Brome treatment

May
Date

\section{3}

Annual grass

Date
June

July

August

SE

Undisturbed

Suppressed

Current year ${ }^{2}$

Undisturbed

Suppressed

Total $^{2}$

Undisturbed

Suppressed

1994

Annual grass

Undisturbed

Suppressed

Current year $^{2}$

Undisturbed

Suppressed

Total $^{2}$

Undisturbed

Suppressed

1995

Annual grass

Undisturbed

Suppressed

Current year ${ }^{2}$

Undisturbed

Suppressed

Total $^{2}$

Undisturbed

Suppressed

$141^{\mathrm{Da} 1}$
$13^{\mathrm{Ab}}$
$681^{\mathrm{Ca}}$
$470^{\mathrm{Ca}}$
$906^{\mathrm{Ca}}$
$726^{\mathrm{Ca}}$

$426^{\mathrm{Aa}}$
$12^{\mathrm{Ab}}$

$$
386^{\mathrm{Ba}}
$$$$
29^{\mathrm{Ab}}
$$$$
246^{\mathrm{Ca}}
$$$$
1,318^{\mathrm{Ba}}
$$$$
867^{\mathrm{Bb}}
$$

$1,660^{\mathrm{Aa}}$

$1,284^{\mathrm{Ab}}$

$$
1,556^{\mathrm{ABa}}
$$$$
1,480^{\mathrm{Aa}}
$$$$
1,534^{\mathrm{Ba}}
$$$$
1,080^{\mathrm{Bb}}
$$$$
1,893^{\mathrm{Aa}}
$$$$
1,409^{\mathrm{ABb}}
$$$$
1,684^{\mathrm{Ba}}
$$$$
1,580^{\mathrm{Aa}}
$$

$30^{\mathrm{Aa}}$
$4^{\mathrm{Aa}}$

$$
88^{\text {Aa }}
$$$$
49^{\mathrm{Aa}}
$$$$
42^{\mathrm{Aa}}
$$$$
4^{\mathrm{Aa}}
$$$$
19^{\mathrm{Aa}}
$$$$
2^{\mathrm{Aa}}
$$$$
778^{\mathrm{Ca}} \quad 1,203^{\mathrm{Aa}}
$$$$
905^{\mathrm{Aa}}
$$$$
1,001^{\mathrm{Aa}}
$$$$
1,081^{\mathrm{ABa}}
$$$$
1,100^{\mathrm{Aa}}
$$$$
897^{\mathrm{BCa}}
$$$$
609^{\mathrm{Bb}}
$$$$
1,737^{\mathrm{Aa}}
$$$$
1,798^{\mathrm{Aa}}
$$$$
1,660^{\mathrm{Aa}}
$$$$
1,572^{\mathrm{ABa}}
$$$$
1,758^{\mathrm{Aa}}
$$$$
1,372^{\mathrm{Ba}}
$$$$
950^{\mathrm{Bb}}
$$

, $745^{\mathrm{A}}$

$$
\begin{array}{r}
131^{\mathrm{Ca}} \\
27^{\mathrm{Bb}} \\
829^{\mathrm{Ca}} \\
821^{\mathrm{Ca}} \\
1,461^{\mathrm{Ca}} \\
1,210^{\mathrm{Ba}}
\end{array}
$$$$
310^{\mathrm{Ba}}
$$$$
140^{\mathrm{Ab}}
$$$$
432^{\mathrm{Aa}}
$$$$
102^{\mathrm{ABb}}
$$$$
184^{\mathrm{Ca}}
$$$$
69^{\mathrm{ABb}}
$$$$
1,440^{\mathrm{Ba}}
$$$$
1,423^{\mathrm{Aa}}
$$$$
1,756^{\mathrm{Aa}}
$$$$
1,437 \mathrm{Ab}
$$$$
967^{\mathrm{Ca}}
$$$$
1,077^{\mathrm{Ba}}
$$

$1,891^{\mathrm{Ba}}$

$1,703^{\mathrm{Aa}}$

$2,326^{\mathrm{Aa}}$

$1,786^{\mathrm{Ab}}$

$1,309^{\mathrm{Ca}}$

$1,322^{\mathrm{Ba}}$

${ }^{1}$ Comparison of date effect for each brome suppression treatment (within a row) is indicated by uppercase superscript. Comparison of brome suppression treatment effect for each component and year (within a column) is indicated by lower case superscript. Means with similar superscripts are not significantly different $(\mathrm{P} \leq 0.05)$.

${ }^{2}$ Current year refers to plant material grown during the current year and total includes both current year plant material and residual plant material from previous years.

\section{Forage Nutritional Quality \\ Ungrazed from Cages}

Brome suppression usually increased the forage nutritional quality of western wheatgrass, Japanese brome, and standing dead (Table 3) in 1993 and 1994, years immediately after brome suppression. The findings suggest Japanese brome plants escaping suppression exhibited higher quality than undisturbed brome plants. Digestibility of standing dead decreased slightly $(\mathrm{P} \leq 0.05)$ from $47.2 \%$ to $43 \%$ with brome suppression, but IVDOM of other species groups was not affected (Table 3).

\section{Grazed}

Crude protein: Response to brome suppression varied with year and date. Averaged across dates, brome suppression increased CP in western wheatgrass in 1993 and 1994, but not 1995 (Table 5). affected by brome suppression $(\mathrm{P}=0.21$; data not shown). While the concentration declined significantly $(\mathrm{P} \leq 0.05)$ from $0.043 \%$ in May to 0.016 in July 1993, values did not differ among dates in 1994 or 1995.

IVDOM: Digestibility of standing dead decreased $(\mathrm{P} \leq 0.01)$ with advancing date with both treatments in 1993 but not in 1994 or 1995. Digestibility tended to increase with advancing date when brome was suppressed in 1994. Digestibility varied among dates within years in western wheatgrass $(\mathrm{P}$ $\leq 0.01)$, blue grama $(\mathrm{P} \leq 0.05)$, and forbs ( $\mathrm{P} \leq$ 0.01; Fig. 2). Obtaining a good estimate of trends in IVDOM of Japanese brome was difficult due to lack of sufficient material for sampling.

\section{Discussion}

Abundance of brome is dependent upon the seedbank (Karl et al. 1999), temperature, and amount and distribution of precipitation (Haferkamp et al. 1993, Whisenant 1990). Suppression of brome requires reduction of annual brome seedbank through environmental and/or managerial (burning, herbicide, hand removal, grazing) means. Suppression of annual bromes is a continuing challenge. Adequate residual seed may be available even after 2 years of suppression to allow an increase in brome abundance, as occurred in 1995 of this study.

Amount and distribution of autumn precipitation are critical for seedling emergence, and spring and summer precipitation are critical for seedling and plant growth. Unusual events such as the prolonged period of precipitation in $1993 \mathrm{kept}$ plants growing later into the grazing season than usually occurs. Haferkamp et al. (1993) reported that the most important factors affecting annual brome production in spring 1983 through spring 1990 were monthly precipitation in October, January, and April; 2-month precipitation totals in March and April and average temperature in January and February; and 3-month precipitation totals in March to May and average temperatures in March and May and September through November. Brome is often abundant when autumn precipitation is high, spring precipitation is high after a dry fall and winter, and distribution is adequately uniform to allow the soil to remain wet for 3 to 5 days. A dry autumn (1993) and spring (1994) reduced brome abundance in 1994. Autumn precipitation in $1992(77 \mathrm{~mm})$ and $1994(83 \mathrm{~mm})$ was 12 and $20 \%$, respectively, above the long- 
Table 3. Least-squares means $\pm \mathrm{SE}$ of percentage $\mathrm{CP}$ concentration for the year by brome suppression treatment interaction for western wheatgrass and Japanese brome and for years averaged across treatments for blue grama. Least-square means of percentage IVDOM concentration for years averaged across treatments for western wheatgrass, Japanese brome, and standing dead, for samples harvested from cages in August each year.

\begin{tabular}{|c|c|c|c|c|}
\hline \multirow{2}{*}{$\begin{array}{l}\text { Component } \\
\text { Brome treatment }\end{array}$} & \multicolumn{4}{|c|}{ Year } \\
\hline & 1993 & 1994 & 1995 & SE \\
\hline $\begin{array}{l}\text { Western wheatgrass } \\
\text { Undisturbed } \\
\text { Suppressed }\end{array}$ & $\begin{array}{c}7.8^{\mathrm{Ab} 1} \\
10.8^{\mathrm{Aa}}\end{array}$ & $\begin{array}{l}3.4^{\mathrm{Cb}} \\
5.2^{\mathrm{Ba}}\end{array}$ & $\begin{array}{l}5.7^{\mathrm{Ba}} \\
5.2^{\mathrm{Ba}}\end{array}$ & 0.36 \\
\hline $\begin{array}{l}\text { Japanese brome } \\
\text { Undisturbed } \\
\text { Suppressed }\end{array}$ & $\begin{array}{r}4.1 \pm 0.71^{\mathrm{Ab}} \\
10.9 \pm 1.00^{\mathrm{Aa}}\end{array}$ & $\begin{array}{l}3.2 \pm 0.71^{\mathrm{Aa}} \\
6.1 \pm 1.00^{\mathrm{Ba}}\end{array}$ & $\begin{array}{l}4.0 \pm 0.71^{\mathrm{Aa}} \\
3.6 \pm 0.71^{\mathrm{Ba}}\end{array}$ & \\
\hline Blue grama & $10.4^{\mathrm{A}}$ & $4.5^{\mathrm{C}}$ & $7.6^{\mathrm{B}}$ & 0.35 \\
\hline $\begin{array}{l}\text { Standing dead } \\
\text { Undisturbed } \\
\text { Suppressed }\end{array}$ & $\begin{array}{l}5.1^{\mathrm{ABb}} \\
7.0^{\mathrm{Aa}}\end{array}$ & $\begin{array}{l}3.9^{\mathrm{Bb}} \\
5.4^{\mathrm{Ba}}\end{array}$ & $\begin{array}{l}6.1^{\mathrm{Aa}} \\
5.3^{\mathrm{Ba}}\end{array}$ & 0.46 \\
\hline $\begin{array}{l}\text { Western wheatgrass } \\
\text { Japanese brome }\end{array}$ & $\begin{array}{l}54.5^{\mathrm{C}} \\
38.7 \pm 1.86^{\mathrm{B}}\end{array}$ & $\begin{array}{l}60.5^{\mathrm{A}} \\
50.0 \pm 1.41^{\mathrm{A}}\end{array}$ & $\begin{array}{l}56.5^{\mathrm{B}} \\
42.8 \pm 1.48^{\mathrm{B}}\end{array}$ & 0.60 \\
\hline Standing dead & $38.7^{\mathrm{C}}$ & $49.3^{\mathrm{A}}$ & $47.3^{\mathrm{B}}$ & 0.55 \\
\hline
\end{tabular}

${ }^{1}$ Comparison of year effect for each species group or brome suppression treatment (within a row) is indicated by uppercase superscripts. Comparison of brome suppression treatment effect on western wheatgrass, Japanese brome, and standing dead for each year (within a column) is indicated by lower case superscripts. Means with similar superscripts are not significantly different $(\mathrm{P} \leq 0.05)$.

term 69-mm average, and abundance of brome was relatively high in 1993 and 1995. A wet spring in 1991 after a dry autumn and winter in 1990 was adequate to provide a productive annual brome year.

Growing-season precipitation influences size and nutritional quality of standing crop and amount of standing dead remaining in pastures. Cool temperatures and above average precipitation in March, April, June, and July 1993 (Fig. 1), produced more forage than steers could consume. Thus, standing crop increased through the summer, and forage quality remained relatively high. Increased growth in 1993 provided large amounts of biomass that were measured as standing dead throughout 1994. This large amount of current-dead biomass may have prevented spray from reaching the soil surface and reduced the effectiveness of atrazine applied in November 1993. Below average precipitation in March and May through August 1994 reduced standing crop, and forced us to remove steers from pastures early in August 1994. Near average precipitation in 1995 produced standing crops similar to 1993 except in August.

We used the $0.5 \mathrm{~kg}$ a.i. ha ${ }^{-1}$ rate of atrazine to reduce suppression of perennial grasses and sedges encountered in other studies with higher rates of application (Hart et al. 1995, Currie et al. 1987, Hewlett et al. 1981, Houston 1977) and to reduce the increase in $\mathrm{N}$ concentration often found in plants treated with sublethal doses of triazine herbicides (Miller and ply reflect the difference in degree of brome suppression. Hand pulling seedlings provides a higher degree of brome suppression than chemical treatment. However, these other studies did not contain any data from years with as little precipitation as 1994. Annual bromes simply do not establish or grow well during dry growing seasons.

The increase in forage $\mathrm{CP}$ of western wheatgrass with brome suppression agrees with other findings at this location (Haferkamp and others 1998, file data). We found a slight but significant increase in CP concentration of western wheatgrass ( 8.3 to $9.0 \%$ ) with hand removal of brome seedlings before 15 May 1995. In contrast, Currie et al. (1987) found only slight nonsignificant differences in CP concentration in herbage sampled in early July from a blue grama-western wheatgrass dominated plant community sprayed 1 to 2 years earlier with atrazine at $0.6 \mathrm{~kg}$ a.i. $\mathrm{ha}^{-1}$. This increase in quality may result as brome suppression reduces use of soil water and allows perennial forages to continue growing later into the grazing season. Brome suppression also creates a forage base with less senesced brome and more actively growing green perennial plants than occurs on adjacent pastures with brome present.

Crude protein concentrations may have also been increased, particularly in 1993, by the effect of sublethal doses of atrazine on indigenous perennial species. The effect of suppression of competition has not been totally differentiated from the enhancement by the sublethal dose. This is in part due to the similarity of responses resulting from suppression of competition or from sublethal doses of triazine herbicides. In a few cases where perennial coolseason grasses were grown without competition, applications of simazine [2chloro-4,6 bis (ethylamino)-s-triazine] Haferkamp et al 1997, 1998). The lack of agreement among these studies may sim-

Table 4. Least-squares means $\pm \mathrm{SE}$ for percentage $\mathrm{CP}$ concentration for significant year by brome suppression treatment interactions in grazed samples.

\begin{tabular}{|c|c|c|c|}
\hline \multirow{2}{*}{$\begin{array}{l}\text { Species group } \\
\text { Brome treatment }\end{array}$} & \multicolumn{3}{|c|}{ Year } \\
\hline & 1993 & 1994 & 1995 \\
\hline \multicolumn{4}{|l|}{ Western wheatgrass } \\
\hline Undisturbed & $10.7 \pm 0.41^{\mathrm{Ab} 1}$ & $9.5 \pm 0.41^{\mathrm{Ab}}$ & $9.7 \pm 0.41^{\mathrm{Aa}}$ \\
\hline Suppressed & $14.8 \pm 0.41^{\mathrm{Aa}}$ & $11.4 \pm 0.41^{\mathrm{Ba}}$ & $10.5 \pm 0.41^{\mathrm{Ba}}$ \\
\hline \multicolumn{4}{|l|}{ Japanese brome } \\
\hline Undisturbed & $8.2 \pm 0.39^{\mathrm{Ab}}$ & $9.0 \pm 0.39^{A}$ & $8.2 \pm 0.39^{\mathrm{Ab}}$ \\
\hline Suppressed & $13.9 \pm 0.44^{\mathrm{Aa}}$ & - & $10.3 \pm 0.39^{\mathrm{Ba}}$ \\
\hline \multicolumn{4}{|l|}{ Forbs } \\
\hline Undisturbed & $16.7 \pm 0.60^{\mathrm{Ab}}$ & $11.4 \pm 0.60^{\mathrm{Bb}}$ & $11.6 \pm 0.60^{\mathrm{Ba}}$ \\
\hline Suppressed & $21.8 \pm 0.60^{\mathrm{Aa}}$ & $13.9 \pm 0.85^{\mathrm{Ba}}$ & $12.4 \pm 0.60^{\mathrm{Ba}}$ \\
\hline
\end{tabular}

${ }^{1}$ Comparison of year effect for each brome suppression treatment (within a row) is indicated by uppercase superscripts. Comparison of brome suppression treatment effect for each year (within a column) is indicated by lower case superscripts. Means with similar superscripts are not significantly different $(\mathrm{P} \leq 0.05)$. 

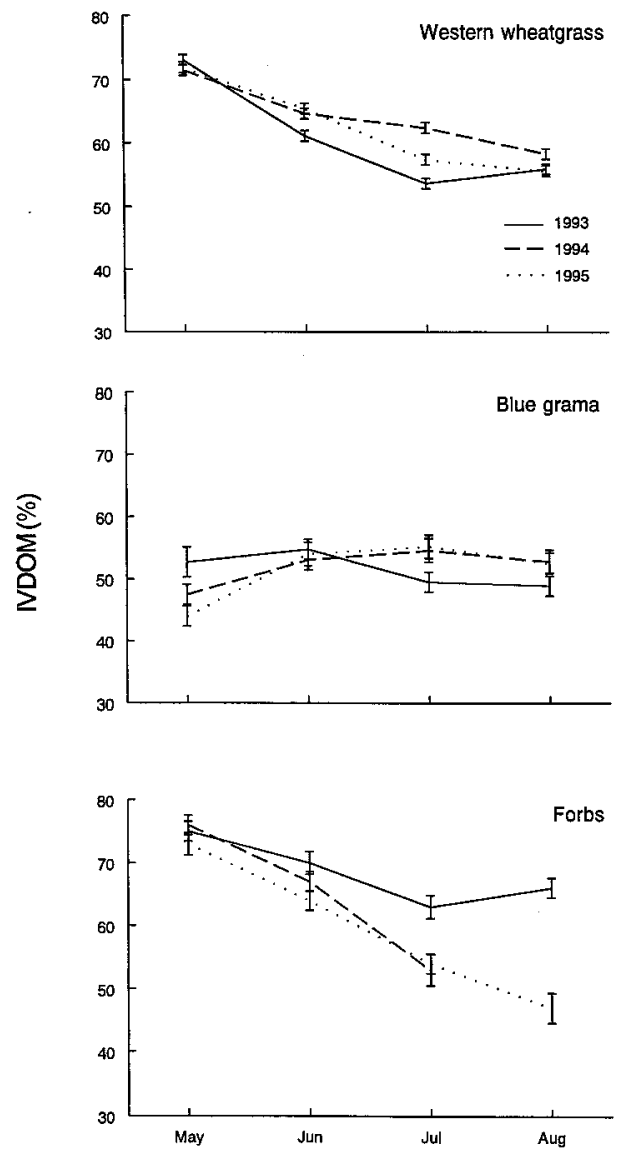

Fig. 2. Least squares means \pm standard errors for percentage IVDOM concentration of significant date by year interactions for western wheatgrass, blue grama, and forbs.
Table 5. Least-squares means $\pm \mathrm{SE}$ for percentage $\mathrm{CP}$ concentration for significant brome suppression treatment by date and year by date interactions in grazed samples.

\begin{tabular}{|c|c|c|c|c|}
\hline \multirow{2}{*}{$\begin{array}{l}\text { Component } \\
\text { Brome treatment/year }\end{array}$} & \multirow[b]{2}{*}{ May } & \multicolumn{2}{|r|}{ Date } & \multirow[b]{2}{*}{ August } \\
\hline & & June & July & \\
\hline $\begin{array}{l}\text { Western wheatgrass } \\
\text { Undisturbed } \\
\text { Suppressed }\end{array}$ & $\begin{array}{l}15.4 \pm 0.35^{\mathrm{Ab} 1} \\
19.4 \pm 0.35^{\mathrm{Aa}}\end{array}$ & $\begin{array}{l}11.4 \pm 0.35^{\mathrm{Bb}} \\
13.3 \pm 0.35^{\mathrm{Ba}}\end{array}$ & $\begin{array}{l}7.1 \pm 0.35^{\mathrm{Cb}} \\
9.1 \pm 0.35^{\mathrm{Ca}}\end{array}$ & $\begin{array}{l}6.0 \pm 0.35^{\mathrm{Db}} \\
7.1 \pm 0.35^{\mathrm{Da}}\end{array}$ \\
\hline $\begin{array}{l}\text { Japanese brome } \\
\text { Undisturbed } \\
\text { Suppressed }\end{array}$ & $\begin{array}{l}15.0 \pm 0.60^{\mathrm{Ab}} \\
\text { non. est. }\end{array}$ & $\begin{array}{l}9.7 \pm 0.60^{\mathrm{Ba}} \\
\text { non. est. }\end{array}$ & $\begin{array}{l}4.9 \pm 0.60^{\mathrm{Cb}} \\
\text { non. est. }\end{array}$ & $\begin{array}{l}4.2 \pm 0.60^{C} \\
\text { non. est. }\end{array}$ \\
\hline $\begin{array}{l}\text { Forbs } \\
\text { Undisturbed } \\
\text { Suppressed }\end{array}$ & $\begin{array}{l}16.7 \pm 0.63^{\mathrm{Ab}} \\
20.3 \pm 0.63^{\mathrm{Aa}}\end{array}$ & $\begin{array}{l}14.3 \pm 0.63^{\mathrm{Bb}} \\
16.4 \pm 0.63^{\mathrm{Ba}}\end{array}$ & $\begin{array}{l}11.7 \pm 0.63^{\mathrm{Ca}} \\
11.9 \pm 0.71^{\mathrm{Ca}}\end{array}$ & $\begin{array}{l}10.3 \pm 0.63^{\mathrm{Cb}} \\
15.7 \pm 0.87^{\mathrm{Ba}}\end{array}$ \\
\hline $\begin{array}{l}\text { Western wheatgrass } \\
1993 \\
1994 \\
1995\end{array}$ & $\begin{array}{l}18.7 \pm 0.43^{\mathrm{Aa}} \\
16.9 \pm 0.43^{\mathrm{Ab}} \\
16.6 \pm 0.43^{\mathrm{Ab}}\end{array}$ & $\begin{array}{l}12.5 \pm 0.43^{\mathrm{Ba}} \\
12.4 \pm 0.43^{\mathrm{Ba}} \\
12.1 \pm 0.43^{\mathrm{Ba}}\end{array}$ & $\begin{array}{r}10.0 \pm 0.43^{\mathrm{Ca}} \\
8.0 \pm 0.43^{\mathrm{Cb}} \\
6.3 \pm 0.43^{\mathrm{Cc}}\end{array}$ & $\begin{array}{l}9.9 \pm 0.43^{\mathrm{Ca}} \\
4.4 \pm 0.43^{\mathrm{Db}} \\
5.4 \pm 0.50^{\mathrm{Cb}}\end{array}$ \\
\hline $\begin{array}{l}\text { Japanese brome } \\
1993 \\
1994 \\
1995\end{array}$ & $\begin{array}{l}18.4 \pm 0.73^{\mathrm{Aa}} \\
\text { non. est. } \\
17.0 \pm 0.73^{\mathrm{Aa}}\end{array}$ & $\begin{array}{l}9.9 \pm 0.85^{\mathrm{Ba}} \\
\text { non. est. } \\
11.5 \pm 0.73^{\mathrm{Ba}}\end{array}$ & $\begin{array}{l}8.4 \pm 0.73^{\mathrm{Ba}} \\
\text { non. est. } \\
4.7 \pm 0.73^{\mathrm{Cb}}\end{array}$ & $\begin{array}{l}7.6 \pm 0.85^{\mathrm{Ba}} \\
\text { non. est. } \\
3.7 \pm 0.73^{\mathrm{Cb}}\end{array}$ \\
\hline $\begin{array}{l}\text { Blue grama } \\
1993 \\
1994 \\
1995\end{array}$ & $\begin{array}{r}11.2 \pm 0.49^{\mathrm{Aa}} \\
9.8 \pm 0.49^{\mathrm{Aa}} \\
10.4 \pm 0.57^{\mathrm{Aa}}\end{array}$ & $\begin{array}{r}10.0 \pm 0.49^{\mathrm{ABa}} \\
9.6 \pm 0.49^{\mathrm{Aa}} \\
10.8 \pm 0.57^{\mathrm{Aa}}\end{array}$ & $\begin{array}{l}9.1 \pm 0.49^{\mathrm{Ba}} \\
6.9 \pm 0.58^{\mathrm{Bb}} \\
6.8 \pm 0.57^{\mathrm{Bb}}\end{array}$ & $\begin{array}{l}9.5 \pm 0.49^{\mathrm{Ba}} \\
4.9 \pm 0.58^{\mathrm{Cc}} \\
6.8 \pm 0.49^{\mathrm{Bb}}\end{array}$ \\
\hline $\begin{array}{l}\text { Forbs } \\
1993 \\
1994 \\
1995\end{array}$ & $\begin{array}{l}20.3 \pm 0.77^{\mathrm{Aa}} \\
18.0 \pm 0.77^{\mathrm{Ab}} \\
17.2 \pm 0.77^{\mathrm{Ab}}\end{array}$ & $\begin{array}{l}17.9 \pm 0.77^{\mathrm{Ba}} \\
14.2 \pm 0.77^{\mathrm{Bb}} \\
13.8 \pm 0.77^{\mathrm{Bb}}\end{array}$ & $\begin{array}{r}16.8 \pm 0.77^{\mathrm{Ba}} \\
8.4 \pm 0.91^{\mathrm{Cb}} \\
10.2 \pm 0.77^{\mathrm{Cb}}\end{array}$ & $\begin{array}{r}22.1 \pm 0.77^{\mathrm{Aa}} \\
9.9 \pm 1.19^{\mathrm{Cb}} \\
7.0 \pm 0.77^{\mathrm{Dc}}\end{array}$ \\
\hline $\begin{array}{l}\text { Standing dead } \\
1993 \\
1994 \\
1995\end{array}$ & $\begin{array}{l}4.3 \pm 0.35^{\mathrm{Bb}} \\
6.9 \pm 0.35^{\mathrm{Aa}} \\
6.5 \pm 0.35^{\mathrm{Aa}}\end{array}$ & $\begin{array}{l}5.2 \pm 0.35^{\mathrm{ABb}} \\
7.4 \pm 0.35^{\mathrm{Aa}} \\
5.4 \pm 0.35^{\mathrm{Bb}}\end{array}$ & $\begin{array}{l}5.3 \pm 0.35^{\mathrm{Ab}} \\
6.5 \pm 0.35^{\mathrm{Aa}} \\
5.0 \pm 0.35^{\mathrm{Bb}}\end{array}$ & $\begin{array}{l}5.1 \pm 0.35^{\mathrm{ABab}} \\
4.4 \pm 0.35^{\mathrm{Bb}} \\
5.7 \pm 0.35^{\mathrm{ABa}}\end{array}$ \\
\hline
\end{tabular}

${ }^{1}$ Comparison of date effect for each brome suppression treatment or year (within a row) is indicated by upper case superscripts. Comparison of brome suppression treatments or years for each date (within a column) is indicated by lower case superscripts. Means with similar superscripts are not significantly different $(\mathrm{P} \leq 0.05)$.

${ }^{2}$ Non-est. = years with non-estimable least-square-means due to lack of available sample for chemical analysis. increased CP concentrations from $10.0 \%$ to $12.2 \%$ (Allison and Peters 1970). Nitrogen concentrations increased from $1.49 \%$ to $2.33 \%$ in blue grama leaves treated with atrazine (Morgan and Knight 1991).

Miller and Doxtader (1995) cautioned that apparent increases in $\mathrm{CP}$ concentration may only be increases in mineral $\mathrm{N}$ concentration. This was not so in the western wheatgrass samples from our study, because $\mathrm{NO}_{3}-\mathrm{N}$ concentrations were very low, less than $0.05 \%$, and did not differ between treated and untreated pastures. The low values are a reflection of $\mathrm{N}$ and water being the major factors limiting plant growth on Northern Great Plains rangelands (Halvorson and White 1981). The limiting effect of soil $\mathrm{N}$ has been demonstrated many times by the increase in forage production with the addition of $\mathrm{N}$ from chemical fertilizer (White 1985, Wight 1976, Lorenz and Rogler 1972).

Similar to our findings, others have found the largest differences between tri- azine treated and untreated plants occur during the spring after treatment the previous autumn, and the differences become progressively smaller during summer and following years (Houston and van der Sluijs 1975). Rhem (1984), however, found no increase in CP concentration of perennial, warm-season grasses with atrazine application when plants were harvested in early to mid-August.

Brome suppression definitely increased forage quality of western wheatgrass, a dominant perennial cool-season grass on Northern Great Plains ranges. Gains of steers were also increased $16 \%$ by suppression of annual bromes (Haferkamp et al. 2001). However, impact of brome suppression on livestock depends on the amount of annual brome infestation, the uniformity of annual brome infestation, and amount of annual brome consumed by grazing livestock. Standing crop of annual grasses was relatively small in 1993 through 1995, when compared to 1989 and 1990 (Haferkamp et al. 1993), 1991, and communities studied by other researchers (Heitschmidt et al. 1995, Whisenant 1990, Currie et al. 1987). However, the untreated pastures in our study were uniformly infested by annual bromes. With these conditions, livestock gains may be impacted more than in studies where animals grazed pastures with spotty distributions of annual brome that allowed greater selection of other herbage by the grazing animal.

\section{Literature Cited}

Allison, D.W. and R.A. Peters. 1970. Influence of simazine on crude protein and cellulose content and yield of forage grasses. Agron. J. 62:246-250.

AOAC. 1990. Official methods of analysis. Assoc. Off. Anal. Chem. 15 ${ }^{\text {th }}$ Ed. Washington, DC.

Cline, J.F. and E.F. Rickard. 1993. Herbage yields in relation to soil water and assimilated nitrogen. J. Range Manage. 26:296-298.

Currie, P.O., J.D. Volesky, T.O. Hilken, and R.S. White. 1987. Selective control of annual bromes in perennial grass stands. J. Range Manage. 40:547-550. 
Fleming, C.E., M.A. Shipley, and M.R. Miller. 1942. Broncograss (Bromus tectorum) on Nevada ranges. Nev. Agr. Exp. Sta. Bull. 159. Reno, Nev.

Gartner, F.R., E.M. White, and R.I Butterfield. 1986. Mechanical treatment and burning for high quality range forage, p.135140. In: South Dakota Beef Report, Animal Range Sciences Dept., Agr. Exp. Sta., Coop. Ext. Serv., South Dakota State Univ., Brookings, S. Dak.

Haferkamp, M.R. and R.K. Heitschmidt. 1999. Japanese brome impacts on western wheatgrass in Northern Great Plains rangelands: An update. Great Plains Research 9:315-327.

Haferkamp, M.R., R.K. Heitschmidt, and M.G. Karl. 1997. Influence of Japanese brome on western wheatgrass yield. J. Range Manage. 50:44-50.

Haferkamp, M.R., R.K. Heitschmidt, and M.G. Karl. 1998. Clipping and Japanese brome reduce western wheatgrass standing crop. J. Range Manage. 51:692-698.

Haferkamp, M.R., E.E. Grings, R.K. Heitschmidt, M.D. MacNeil, and M.G. Karl. 2001. Suppression of annual brome impacts rangeland: Animal responses. J. Range Manage. 54:663-668.

Haferkamp, M.R., J.D. Volesky, M.M. Borman, R.K. Heitschmidt, and P.O. Currie. 1993. Effects of mechanical treatments and climatic factors on the productivity of Northern Great Plains rangelands. J. Range Manage. 46:346-350.

Haferkamp, M.R., J.A. Young, E.E. Grings, M.G. Karl, R.K. Heitschmidt, and M.D MacNeil. 1994. Japanese brome in the Northern Great Plains, p.396-401. In: S.B. Monsen and S.G. Kitchen (eds.) Proc.-Ecology and management of annual rangelands. 18-21 May 1992. Boise, Ida., USDA-FS Gen. Tech. Rep. INTGTR 313. Ogden, Ut.

Halvorson, A.D. and L.M. White. 1981. Nitrogen fertilization effects on seasonal $\mathrm{Ca}$, $\mathrm{Mg}, \mathrm{P}$, and $\mathrm{K}$ levels of western wheatgrass and green needlegrass. Agron. J. 73:651-656.

Hart, R.H., M.C. Shoop, and M.M. Ashby. 1995. Nitrogen and atrazine on shortgrass: Vegetation, cattle and economic responses. J. Range Manage. 48:165-171.
Heitschmidt, R.K., E.E. Grings, M.R. Haferkamp, and M.G. Karl. 1995. Herbage dynamics on 2 Northern Great Plains range sites. J. Range Manage. 48:211-217.

Hewlett, D.B., J.R. Johnson, R.I. Butterfield, and V.K. Mosley. 1981. Japanese brome response to atrazine in combination with nitrogen fertilizer in the mixed prairie. J. Range Manage. 34:22-25.

Houston, W.R. 1977. Species susceptibility to atrazine herbicide on shortgrass range. J. Range Manage. 30:50-52.

Houston, W.R. and D.H. van der Sluijs. 1975. S-triazine herbicides combined with nitrogen fertilizer for increasing protein on shortgrass range. J. Range Manage. 28:372-376.

Karl, M.G., R.K. Heitschmidt, and M.R. Haferkamp. 1999. Vegetation biomass dynamics and patterns of sexual reproduction in northern mixed-grass prairie. Amer. Midl. Nat. 141:227-237.

Kay, B.L. 1971. Atrazine and simazine increase yield and quality of range forage. Weed Sci. 19:370-372.

Kuchler, A.W. 1964. Potential natural vegetation of the conterminous United States. Amer. Geog. Soc. Spec. Pub. 36. Amer. Geog. Soc. New York, N.Y.

Lorenz, R.J. and G.A. Rogler. 1972. Forage production and botanical composition of mixed prairie as influenced by nitrogen and phosphorus fertilization. Agron. J. 64:244-249.

Mayland, H.F., R.B. Murray, and G.E. Shewmaker. 1994. Forage yields and quality trends of annual grasses in the Great Basin, p. 387-391. In: S.B. Monsen and S.G. Kitchen (eds.) Proc.-Ecology and management of annual rangelands. 18-21 May 1992. Boise, Ida., USDA-FS Gen. Tech. Rep. INT-GTR 313. Ogden, Ut.

McLendon, T. and E.F. Redente. 1994. Role of nitrogen availability in the transition from annual-dominated to perennial dominated seral communities, p. 352-362. In: S.B. Monsen and S.G. Kitchen (eds.) Proc.-Ecology and management of annual rangelands. 18-21 May 1992. Boise, Ida., USDA-FS Gen. Tech. Rep. INT-GTR 313. Ogden, Ut.

Miller, M.S. and K.G. Doxtader. 1995. Atrazine impacts on shortgrass prairie microcosms. J. Range Manage. 48:298-306.
Morgan, J.A. and W.G. Knight. 1991. Growth and physiological responses of greenhousegrown blue grama to atrazine. Agron. J. 83:677-683.

Mosley, J.C. 1996. Prescribed sheep grazing to suppress cheatgrass: A review. Sheep and Goat Res. J. 12:74-81.

National Oceanic and Atmospheric Administration. 1990-1995. Climatological data annual summary, Montana. 93-98:13.

Rehm, G.W. 1984. Yield and quality of a warmseason grass mixture treated with $\mathrm{N}, \mathrm{P}$, and atrazine. Agron. J. 76:731-734.

Rummell, R.S. 1946. Some effects of competition from cheatgrass brome on crested wheatgrass and bluestem wheatgrass. Ecol. 27:159-167.

SAS. 1990. SAS/STAT user's guide. Vol. 2, Version 6 (4th Ed.). SAS Inst. Inc. Cary, N.C.

Technicon Industrial Systems. 1977. Digestion and sample preparation for the analysis of total Kjeldahl nitrogen/phosphorus using the Technicon BD-20 block digester. Technicon Autoanalyzer II Methodology. Industrial Method No. 369-75 A/B. Technicon Industrial Systems. Tarrytown, N.Y.

Tilley, J.M.A. and R.A. Terry. 1963. A twostage technique for the in vitro digestion of forage crops. J. Brit. Grassl. Soc. 18:104-111.

Vallentine, J.F. and A.R. Stevens. 1994. Use of livestock to control cheatgrass-a review, p.202-206. In: S.B. Monsen and S.G. Kitchen (eds.) Proc.-Ecology and management of annual rangelands. 18-21 May 1992. Boise, Ida., USDA-FS Gen. Tech. Rep. INT-GTR 313. Ogden, Ut.

Whisenant, S.G. 1990. Postfire population dynamics of Bromus japonicus. Amer. Midl. Natur. 123:301-308.

White, L.M. 1985. Long-term residual effects of nitrogen fertilization on western wheatgrass. J. Range Manage. 38:461-466.

White, L.M., G.P. Hartman, and J.W. Bergman. 1981. In vitro digestibility, crude protein, and phosphorus content of straw of winter wheat, spring wheat, barley, and oat cultivars in eastern Montana. Agron. J. 73:117-121.

Wight, J.R. 1976. Range fertilization in the Northern Great Plains. J. Range Manage. 29:180-185. 